\title{
Accounting and Social Implications of Twin Problem on the National Economy.
}

\author{
Adediran, S. A ${ }^{1}$., Josiah, Mary², Emmanuel, Ozoh ${ }^{3}$. \\ ${ }^{1,2}$ Department Of Accounting, College Of Business And Managament Studies Igbinedion University, Okada \\ Nigeria. \\ ${ }^{3}$ Department Of Accounting, College Of Management Sciences Veritas University, Obehie Nigeria.
}

\begin{abstract}
The study focuses on the accounting and social implications of twin problem of tax avoidance and tax evasion on the national economy. The data for this study were generated through the use of questionnaires, six hundred were administered while four hundred and fifty were returned. The data returned were analysed through the use of Analysis of Variance (ANOVA) with the help of Statistical Package for Social Sciences (SPSS). It was discovered that shortfall in government revenue is as a result of tax avoidance and evasion which in turn leads to inability of the government to discharge her responsibility of provision of basic amenities to its citizenry. Based on these findings it was recommended that all cases of tax avoidance and evasion should be hence forth made public in order to serve as deterrent to others.
\end{abstract}

Keywords- Accounting, funds, Tax avoidance, tax evasion, National economy,

\section{Introduction}

Tax is not new in our society. It has its origin from the olden days when people had to tax themselves so as to source funds in order to finance community projects. Even, tax has its backing from the two prominent religions (Christianity and Islam). It is reported in the Holy Bible (Matthew 22:17-21) that Jesus told his disciples to give to Caesar what is Caesar's (tax) and to God what is God's. Chapter nine verse eleven of the Holy Quaran quoted as "but if they repent, pray and pay the "poor rate" (tax) they are your brothers in faith". Again, it is commonly said that the only things certain in life are death and taxes; it is unmistakable that taxes are in fact far from being inevitable. Despite all these supports here and there for tax paying, individuals, private companies and corporate bodies do not like paying taxes.

People see tax as a mere undesired levy imposed on them by the Government, and such levy does not justify Governments' responsibilities on the citizenry. In order to avoid the payment of such undesired levy called tax, many devices were employed by the citizenry to either run away completely from its payment or pay less of what were expected of them. Several billions of naira in tax had been lost to tax evaders every year thereby denying Government necessary revenue that would have been used to prosecute and finance fiscal budgets; provision of social amenities, infrastructural development and others. In the area of job creation, much could have been achieved by Government if they have access to all funds (taxes) that had been siphoned into private purses. The inability of the Government to retrieve all these funds (revenue) in private purses have several economic, social, accounting and other implications on the national economy. Hence, the need to consider "the accounting and social implications of tax avoidance and evasion on the national economy".

\section{Objectives of the Study}

The purpose of this study is to investigate the accounting and social implications of tax avoidance and evasion on the national economy. We shall also examine motives for evading tax in Nigeria.

\section{Literature Review}

Tax in its original conception may be regarded as an assessment imposed by the states and the Federal Government to meet the expenses of governing, administering and protecting the nation. Tax is defined by Okoye and Otakefe (2004:41) as a burden, which every citizen must bear to sustain his or her government, apart from the fact that it is a compulsory levy charged by the government through its agent on the income profit and wealth of corporate bodies and individuals. It is unquestionably an essential feature of governmental structure, also a component of any fiscal policy. Despite these, most citizens believe that tax is merely a legal compulsion and an undesirable imposition which bears no relation to the responsibilities of citizenship or to the services provided by the Government. Hence their desire and opportunities for evasion, avoidance and non compliance continue to manifest in their dealings with tax authority. 


\section{Aims of Taxation in Nigeria}

The objective of Government is not only seizure of power and administration alone but for the public good too. This public good encompasses provision of basic amenities and infrastructures, security of life and properties, food sufficiency, job creation, independent and effective judicial system, correct policy framework and others. The attainment of these lofty objectives is facilitated by revenue realized from tax and other sources of revenue by the Government.

Recent economic development and disgressional actions have stimulated new interest in taxation as an instrument of national policy. It is used by the Government to frame its budgets as well as developmental plans in respect of infrastructures and social amenities. Tax is used to restore full employment and raise the rate of economic growth; it is also regarded as an active force in economic planning and development. Tax is used in redistributing income and securing a stable price level within which the economic can grow. To fully enjoy the aim and benefits of tax, a taxation policy must be based on the need to structure taxes in such a way that their effects are beneficial to the economy. An understanding of the incidence of taxation by recognizing the class on which the weight of a tax falls is important at this point.

The fact about the taxation system in Nigeria is that while taxes are considered repressive much trust is reposed on eligible taxpayers who share little of the progressive ideals in which taxation policy is built. The revenue department usually requests taxpayers to come forward and declare their incomes, assets and liabilities. These, they hardly comply with.

\section{Tax Evasion}

The phenomenon of explosive growth in tax evasion is pervasive in a developing economy like Nigeria; the case of tax evasion is not peculiar to Nigeria alone. In fact, it is a worldwide phenomenon. To understand perfectly what tax evasion means, it would be necessary to give its definition as that will bring into focus its accounting and social implication on any economy. According to Adegboyega (1987:105), tax evasion is defined as "an illegal action, deliberately designed to reduce or avoid payment of tax". This could be done through false declaration of non-existing items that would probably reduce the burden of tax on the taxpayer. Tax evasion is a willful and deliberate violation of the law in order to escape payment of tax which is questionably imposed by the law of the tax jurisdiction. It does not only include cheating and fraud of various kinds but also the failure to comply with the law resulting from ignorance or negligence.

One important feature of tax evasion is that the offenders despite the fact that tax evasion is illegitimate and illegal, intentionally do it. The evasion of early direct tax took the form of the comparatively unsophisticated methods of omitting assessable items of income altogether from the returns; scaling down amounts and thus submitting fraudulent returns of income; making erroneous deductions, inaccurate or incomplete returns and appealing against assessment which were supported by deliberate and false accounts.

Tax evasion arises from a consensus failure to comply with the existing laws for varying causes, the tax taken on the national income is relatively small but relatively high on particular taxpayer such taxpayer may seek to evade tax by either leaving the country altogether or by the more likely method of placing their resources of income outside the country with the view to hiding their income and thereby defeating the revenue (Jamita 1994:13).

The taxpayer indulges in evasion by resulting to various abnormal practices; these practices erode moral values and build up inflationary pressure on the economy. These are attributed to the shameful act of tax evasion which renders detection difficult. Secret wealth may be siphoned off to foreign countries through the under-living of experts or through siphoning activities, refuge may be sought in foreign bank accounts or in investments abroad to escape the reach of local news.

\section{Tax Avoidance}

Tax avoidance is the lawful process of organizing one's affairs so as to minimize the overall amount of tax that is required to be paid to the tax authority. Jamita (1994:13) described tax avoidance as the active device by which the taxpayer seeks to reduce or remove completely his liability to tax without actually breaking the law. It is legitimate or lawful though contrary to the spirit of the law; it affects tax savings by making use of loopholes in the law. For instance, omission of a major asset from a tax return could be termed as a deliberate intent. Hence, tax avoidance but basically under tax valuation the action could be intentional or unintentional yet it is a ploy to avoid tax.

Tax avoidance devices take the form of inflating expenses during a high level period and offsetting such expenses against increased profits in subsequent years. In this way, the taxpayer is able to minimize his incidence of taxation by making up the deficiency of earlier years. Avoidance is rather more complex, a taxpayer may legally reduce his tax liability by spending in excess of his income, marrying and have more children. In looking at tax avoidance, one is tempted to ask whether the action which reduces tax liability is something: 
(a) Which the Government specifically seeks to encourage such as exemption for charitable converts or

(b) Whether it is something about which state is central such as to a wife or dependent relatives, or

(c) A method of tax reduction which takes advantage of loopholes because the laws are incompletely framed. Therefore, statutory precautions are necessary to guard against artificial transactions as ingenious methods were constantly being formed by which the legislation could be defeated.

Obviously, in tax avoidance the taxpayer knowing what the tax is, chooses not to be caught by the law but rather chooses to conceal his liability from the taxing authority. Tax avoidance may take several forms. For example, it may result from the failure to file returns of income, failure to report all incomes subject to tax which may be employment income, investment income or business income; fictitious deductions may be claimed or made; improper characterization may be made of income or expense items, improper utilization may be made of temporary tax payer status, fleeing the country to avoid tax payment; failure to keep records or inadequate records; failure to pay to the inland and Internal Revenue Department the estimated tax; payment of tax by means of bad cheques and any other unlawful means employed which seeks to withhold tax which is otherwise payable. Whichever way employed to avoid tax, the fact remains that tax avoidance and tax evasion is a crime to the nation as the action deprives the country from getting adequate funds to provide for the basic needs of the citizenry.

\section{Reasons for Tax Evasion and Tax Avoidance}

Taxpayers have different reasons for indulging in these acts, ranging from economic reasons to social as mentioned below:

1) The taxpayer may perceive certain choices with regard to tax declaration, financial transactions, or economic activity to be potentially costly thereby inimical to his own financial benefits and so, conceal such choices to tax.

2) It may also be felt that due to inflation, the profits from the business no matter how big, may not worth its real value after all. Therefore, to subject such profit to taxation may erode the marginal propensity to consume of individual taxpayer.

3) Some bad eggs among the officers of the inland and Internal Revenue Department also collaborate with the taxpayers for their financial gains (from the taxpayer) in return for helping them to avoid tax. The drastic fall in the real value of fines and penalties applied to tax avoidance and tax evasion or non-prosecution of the tax offenders also encourages tax avoidance and tax evasion.

4) The activities of the people in Government, living ostentatiously, equally contribute to high incidence of tax evasion and tax avoidance. Many taxpayers believe that politicians feed fat with the tax paid, so they do not see any need for paying tax.

5) Majority of taxpayers believe that tax paid is being directed into private pockets and private accounts and so as such, justification for not paying tax.

It will be very difficult to eradicate completely the twin phenomenon called tax evasion and tax avoidance from Nigerian system since those who are vested with tax administration powers are also culprits.

\section{Accounting Implications}

Essentially, knowing what accounting is all about could best explain the accounting implications of tax avoidance and tax evasion. It is defined as "the process of identifying, measuring and communicating economic information to permit informed judgments and decisions by users of the information" Okoye (2000:1).

Some users of accounting information are Investors, Governments, Employees and others, all for different reasons. Government uses accounting information in order to asses the organisation for tax liabilities; also for planning and analysis of economic activities in the country especially during the preparation of development plan.

Now if individuals, private companies and corporate bodies avoid and evade tax, there will be shortfall in the revenue accruing to Government, this make planning and implementation of plans difficult. How will the government plan when the corporate bodies usually file-in nil profit and nil return? How will the economic activities be analyzed in the country when it comes to development plan preparation? With losses and nil return, the revenue that was supposed to be accrued to Government would now be left in the hands of the taxpayers. These taxpayers may or may not have the interest of its immediate community at heart talkless of the generality of the nation. When tax is paid accordingly, the revenue realized would be used for the provision of social amenities, infrastructures and other needs which are deemed necessary for any community. Then if, government looses these revenues to tax evaders; it could negatively affect its ability to provide social amenities, infrastructural facilities and so on. The inability of Government to provide all these has multiplier effects on the nation. ( Makanjuola 1998)

According to Tukur (2002) mentioned that Government may not be able to finance its budgets; when this happens, they will resort to borrowing either locally or intentionally. Either way, both portend bad omen for 
the National Economy. There would be a shortfall in Government's projected revenue thereby resulting in deficit budgets. When government borrows locally, it increases pressure on the local currency; borrowing locally equally increases the Minimum Rediscount Rate (MRR) if there were increased pressure on the local currency; there will be inflation and the value of the currency of the nation will fall, the currency's purchasing power will be less. When this happens, the ability of the nation to export its goods and service is limited. This is because of the low rate at which their currency will be exchanged for other country's currency, exporters who were supposed to earn foreign exchange income for the nation would be discouraged from exporting activities and as such, there will be a reduction in the rate of foreign exchange being earned through export activities. There is this tendency for the country to be a dumping ground because people will be importing unrestrictedly because of the low exchange rate. This is a drain on the National Economy.

Now, if Government borrows internationally collateral (Foreign Reserves) will be used. This increases our foreign debts and the amount of money used in servicing the debts every year impacts negatively on the National Economy. This is so, as the revenue realized from other sources that were supposed to be used in providing social amenities, infrastructures and others will used in servicing debts. Our Foreign Reserve that is supposed to be fixed will be turned to 'current' by frequent use of it.

\section{Social Implications}

The inability of Government to provide essential social services to her citizenry brought about youth restiveness in almost all the nooks and crannies of the country. The much needed social services include funding of education, provision of steady power (electricity), provision of adequate health care system, provision of social amenities, jobs creation and so on are in short supply because of the inability of the government to generate enough revenue.

\section{Methodology}

Data for this research work were collected through the use of questionnaires. Six hundred questionnaires were administered in Edo State while four hundred and fifty were returned. The data generated are presented in the two tables below:

Table I: Response as to whether the inability of Government to provide social services is due to Tax Avoidance/Evasion

\begin{tabular}{|l|l|l|l|l|}
\hline Details & Frequency & Percent & Valid Percent & $\begin{array}{l}\text { Cumulative } \\
\text { Percent }\end{array}$ \\
\hline Strongly Agree & 250 & 55.6 & 55.6 & 55.6 \\
Agree & 160 & 35.6 & 35.6 & 91.2 \\
Disagree & 20 & 4.4 & 4.4 & 95.4 \\
Strongly Disagree & 20 & 4.4 & 4.4 & 100.0 \\
Total & 450 & 100.0 & 100.0 & \\
\hline
\end{tabular}

Source: Data Survey, 2012

As illustrated in table I above, $55.6 \%$ of the respondents strongly agree that the inability of Government to provide social services could be attributed to tax avoidance/evasion, $35.6 \%$ of the respondents agree and $4.4 \%$ disagree while the remaining $4.4 \%$ of the respondents strongly disagree. This means that there is a general consensus among most of the respondents that the inability of Government to provide social services could be attributable to tax avoidance/evasion.

Table II: Response as to whether Tax Avoidance \& Evasion contribute to increase in Social Vices \& Unrest

\begin{tabular}{|l|l|l|l|l|}
\hline Details & Frequency & Percent & Valid Percent & $\begin{array}{l}\text { Cumulative } \\
\text { Percent }\end{array}$ \\
\hline Strongly Agree & 180 & 40.0 & 40.0 & 40.0 \\
Agree & 210 & 46.7 & 46.7 & 86.7 \\
Disagree & 40 & 8.9 & 8.9 & 95.6 \\
Strongly Disagree & 20 & 4.4 & 4.4 & 100.0 \\
Total & 450 & 100.0 & 100.0 & \\
\hline
\end{tabular}

Source: Data Survey, 2012

It can be analyzed from table II that $40 \%$ of the respondents strongly agree that tax avoidance and evasion contribute to increase in social vices and social unrest, $46.7 \%$ of the respondents agree while $8.9 \%$ of the respondents disagree and the remaining $4.4 \%$ strongly disagree. This indicates that majority of the respondents are of the opinion that tax avoidance and evasion contribute to increase in social vices and social 
unrest. The data generated were analysed using Analysis of Variance (ANOVA) through the use of Statistical Package for Social Sciences (SPSS). The result is presented below:

\section{Hypothesis I}

$\mathrm{H}_{0}$ : There is no significant relationship between Government shortfall in revenue and tax avoidance/tax evasion

Table III: Analysis of Variance (ANOVA) Table

ANOVA

\begin{tabular}{|c|c|c|c|c|c|}
\hline & $\begin{array}{l}\text { Sum of } \\
\text { Sauares }\end{array}$ & Df & $\begin{array}{c}\text { Mean } \\
\text { Square }\end{array}$ & $\mathbf{F}$ & Sign \\
\hline Between people & 61.556 & 44 & 1.399 & & \\
\hline Within Between Items & .278 & 1 & .278 & 5.500 & 024 \\
\hline People Residual & 2.222 & 44 & .051 & & \\
\hline Total & 2.500 & 45 & .056 & & \\
\hline Total & 64.056 & 89 & .720 & & \\
\hline
\end{tabular}

Source: SPSS Output, 2012

From the table above, using the ANOVA (Analysis of Variance) method, high value of F suggests that the difference between the two variances is significant, implying a significant different between means of samples and hence the rejection of the null hypothesis which presupposed equality of the means of variance. Also, it will be observed that the $F$ calculated value $\left(F_{c}\right)$ is 5.500 while the F-tabulated value $\left(F_{t}\right)$ is 4.08 at a degree of freedom of between 1 and 44. Since $F_{c}>F_{t}$ i.e the calculated value of $F$ which is 5.500 is greater than its tabulated value which is 4.08 . we reject the null hypothesis $\left(\mathrm{H}_{0}\right)$ which means that there is significant relationship between Government's shortfall in revenue and tax avoidance/tax evasion on the National Economy.

Hypothesis II: There is no significant relationship between Tax avoidance/evasion and increase in social vices and unrest.

\section{Correlation Table}

\begin{tabular}{|c|l|l|}
\hline & Table I & Table II \\
\hline Table I: Pearson Correlation & 1 & $.909^{* *}$ \\
Sig. (2-tailed) & & .000 \\
$\mathrm{~N}$ & 45 & 45 \\
\hline Table II: Pearson Correlation & $.909^{* *}$ & 1 \\
Sig. (2-tailed) & .000 & \\
$\mathrm{~N}$ & 45 & 45 \\
\hline
\end{tabular}

** Correlation is significant at the 0.01 level (2-tailed)

Source: SPSS Output, 2012

From the correlation table, it will be discovered that under the 2-tailed correlation, the coefficient is given as 0.909 which is being translated to $90.9 \%$ and the significance of the correlation is $1 \%$. At $90.9 \%$, the correlation is significant; therefore we reject the null hypothesis which means that, there is a significant relationship between Tax avoidance/evasion and increase in social vice and unrest.

\section{Summary of Findings}

The following findings were highlighted in the course of this study:

1) There is a significant relationship between Government shortfall in revenue and tax avoidance/tax evasion on the National Economy: the study revealed that when tax offenders increase, there will be a shortfall in revenue accruing to the Government and this has a multipler effect on the nation.

2) There is a significant relationship between the inability of the Government to provide essential social services and tax avoidance/tax evasion on the National Economy: when tax offenders increase, Government may not be able to fund education, provide basic amenities, and infrastructural facilities. This portends bad omen to the National Economy.

3) Government should change its orientation about tax: Government's tax orientation is at its lowest ebb and this also discourages the citizenry from fulfilling their civic duties.

4) Certain Accountants aid tax offenders: Accountants who inspect or help prepare financial statements also aid tax offenders by concealing taxable items and inflating expenses.

5) Most people are not well enlightened about tax matters: people fear that the money paid as tax may end up in the private pockets of some politicians.

6) Staff o the board lack adequate training and modern tax collection machinery. 


\section{Conclusion}

The accounting and social implication of tax avoidance and evasion on the National Economy can not be over emphasized. Most citizens, especially in the rural areas are not well educated about tax matters hence; they brand tax as a levy from Government which is aimed at exploiting them. Tax avoidance and evasion do not add anything good to a nation, thus, for it to be minimized, all those that aid it must be ready to make amends. It is only when all and sundry decide to fight tax avoidance/evasion that the implications whether social, accounting or economic will be minimized.

\section{Recommendations}

Based on the exposition and findings of this study, the following recommendations are made:

1) The board of Inland Revenue must be cognizant of the fact that taxpayers cannot comply with the law unless they know and understand what was expected of them. To achieve this, the board should continually strive to educate and simplify the process of tax collection, making it clear and unambiguous to all tax payers.

2) Special effort should be made towards periodic press publications, explanatory pamphlets and information.

3) Circulars and notices to the public in the local languages to ensure that taxpayers understand the charges brought about by the tax laws.

4) Apart from the existing punishment and penalty, cases of tax avoidance should be made public in order to serve as a deterrent to others.

Lastly, professional bodies should educate their members on how to put the ethics of their profession above all personal gains.

\section{References}

[1] Okoye A.E. and Otakefe J. (2004) "Tax consideration in Investment Decision of companies in Nigeria (ed.) Ezejelue and Okoye in Accountancy: Management companion, Nigerian Accounting Association (NAN).

[2] Adegboyega A. (1987): Political Values and Local Government in Nigeria: Malthouse Press, Lagos.

[3] Jamita O.A. (1994): Basic Principles in Theory and Practice of Taxation,: Jamita Limited, Lagos.

[4] Okoye, A.E. (2000) Financial Accounting for Students and Managers Mindex Publishing company Ltd., Benin City.

[5] Makanjuola, J.D.A. (1998): “Improving the Nigerian Tax Administration for the Challenges of the next millennium” being a paper presented at the $28^{\text {th }}$ Annual Seminar: Staff Conference of the Federal Inland Revenue Service, December, 1998.

[6] Tukur, H.A. (2002): "Effective Mobilization of Revenue Resources and Budget Implementation" being a paper presentation at a 2Day Federal Government Budget Office Workshop organized by the Budget Office of the Federation at Abuja Sheraton \& Tower, June $22^{\text {nd }}$. 